\title{
First Report of Entomopathogenic Fungi Occurrence in Forest Soils in Croatia
}

\author{
Marta Kovač $^{1, * \mathbb{D}}$, Cezary Tkaczuk ${ }^{2} \mathbb{D}$ and Milan Pernek ${ }^{1} \mathbb{D}$ \\ 1 Croatian Forest Research Institute, Cvjetno naselje 41, 10450 Jastrebarsko, Croatia; milanp@sumins.hr \\ 2 Institute of Agriculture and Horticulture, Siedlce University of Natural Sciences and Humanities, \\ 08-110 Siedlce, Poland; cezary.tkaczuk@uph.edu.pl \\ * Correspondence: martam@sumins.hr
}

Citation: Kovač, M.; Tkaczuk, C.; Pernek, M. First Report of Entomopathogenic Fungi Occurrence in Forest Soils in Croatia. Forests 2021, 12, 1690. https://doi.org/10.3390/ f12121690

Academic Editors: Lassaâd Belbahri, Justyna A. Nowakowska and Tomasz Oszako

Received: 25 October 2021 Accepted: 30 November 2021 Published: 2 December 2021

Publisher's Note: MDPI stays neutral with regard to jurisdictional claims in published maps and institutional affiliations.

Copyright: (c) 2021 by the authors. Licensee MDPI, Basel, Switzerland. This article is an open access article distributed under the terms and conditions of the Creative Commons Attribution (CC BY) license (https:/ / creativecommons.org/licenses/by/ $4.0 /)$.

\begin{abstract}
Entomopathogenic fungi (EPF) in Croatian forests are known only from observations of insect cadavers that show obvious signs of disease. To date, their presence in soils has not been investigated. The aim of this study was to investigate their occurrence, diversity, and distribution, and to assess their density in tested soils. Soil samples were collected during 2018, 2019, and 2020 at different localities throughout the country, and analyzed by using a method of isolation of fungi on selective culture media. To assess the density of EPF in tested soils, colonies of individual fungal species were counted and recorded; the results were expressed as the number of colony-forming units (CFU) per gram of dry soil. After morphological and molecular analysis, five entomopathogenic fungal genera were identified: Beauveria spp., Metarhizium spp., Purpureocillium spp., Lecanicillium spp., and Paecilomyces spp. Results also showed that the range of a total EPF colony density in the soil varies from $4 \times 10^{3}$ to $27.4 \times 10^{3} \mathrm{CFU} \mathrm{g}^{-1}$. The most common were EPF of the genus Beauveria, which were recorded at four of five locations, and at 16 of 25 sampling points, but the highest average number (density) of colonies belonged to the genus Metarhizium. Since this type of research was never conducted in Croatia previously, this is the first evidence that insect pathogenic fungi are present in soils of different natural forest habitats. Such research can be useful in selecting and utilizing entomopathogens that are suitable for biological pest control in certain target areas.
\end{abstract}

Keywords: Beauveria; Metarhizium; Purpureocillium; Lecanicillium; Paecilomyces; entomopathogens; selective culture media; colony-forming units; biological pest control; natural forests

\section{Introduction}

Entomopathogenic fungi (EPF) have a wide distribution and live in almost all terrestrial ecosystems in the world. Their highest diversity has been recorded in tropical forests, but they can also be found in extreme habitats such as the Arctic [1,2] and Antarctica [3,4]. They are an important factor in the regulation of insect pests that can cause great levels of mortality, and they are capable of breaking down pest populations during outbreaks in forest habitats [5-8]. Among these fungi, Beauveria spp., Metarhizium spp., Isaria (=Cordyceps) spp., and Lecanicillium spp. are common genera found in agricultural and forest soils and have the greatest potential for biological control [9-12].

Many hypocrealean EPF are adapted to the soil, where they spend most of their life cycles, a feature that allows them to infect and utilize not only typical soil-inhabiting pests but also a large group of insect pests that use soil as a site for hibernation, pupation, or periodic diapause [12-15]. It is estimated that soil plays habitat to more than $90 \%$ of all insect pests at some point in their development cycle [16]. Entomopathogenic fungi can exist in the soil as saprophytes, colonizing fragments of insect cadavers and organic matter [17]. Soil is a stable structure that mitigates the fluctuation of their populations and protects them from harmful abiotic influences such as temperature, solar radiation, or drying [18,19]. Many species can be recovered from conventional isolation sites by using specific methods such as isolation on selective culture media [20] or insect-baiting methods [21]. Since a wide 
range of fungi that inhabit soil can grow on artificial media, isolation of certain groups of microorganisms' specific media have been developed, including media for selective isolation of EPF [22].

In Croatia, EPF are known only from observations done on insect cadavers that are showing obvious signs of disease $[8,23,24]$, where in some cases a significant potential to reduce the population [24,25] or even to stop a pest outbreak [8] was demonstrated. However, the presence of EPF in soils has not yet been investigated.

This study is the first overview of EPF in the forest soils of Croatia. The aim of this study was to investigate their occurrence, diversity, and distribution, and to assess their density in tested soils at different locations throughout the country. Results obtained tend to encompass the dominant EPF species and to provide a basis for future investigations, such ase their associations with soil types, $\mathrm{pH}$, tree species composition, dominant pests present, selection, utilization of species suitable in biological pest control, etc. All study sites chosen were natural and climatogenic forests with no tree species that were introduced and cultivated.

\section{Materials and Methods}

\subsection{Sampling Sites and Collection of Soil Samples}

Soil samples were collected during 2018, 2019, and 2020 at different localities in different forests throughout Croatia, which were chosen according to previously studied sites where various insects infested with EPF of genus Beauveria were found [24]. The time of the soil material collection was chosen randomly, according to our ability to do the field survey in the particular locations, as well as the longevity of the laboratory analyses of collected samples. An overview of the locations, including information on insect hosts and identified fungi, is provided in Table 1.

Table 1. Information on sampling sites in Croatia.

\begin{tabular}{|c|c|c|c|c|c|c|c|c|}
\hline$\underset{\text { Sites }}{\text { Sampling }}$ & Coordinates & $\begin{array}{l}\text { Time of } \\
\text { Collection } \\
\text { of Insects }\end{array}$ & $\begin{array}{c}\text { Dominant } \\
\text { Tree } \\
\text { Species }\end{array}$ & $\begin{array}{l}\text { Insect } \\
\text { Host }\end{array}$ & $\begin{array}{c}\text { Development } \\
\text { Stage }\end{array}$ & $\begin{array}{l}\text { Identified } \\
\text { Fungus }\end{array}$ & $\begin{array}{c}\text { Soil } \\
\text { (Type, pH, } \\
\text { Moisture) }\end{array}$ & $\begin{array}{l}\text { Time of } \\
\text { Collection } \\
\text { of Soil }\end{array}$ \\
\hline Skradin & $\begin{array}{l}43^{\circ} 49^{\prime} 08.1^{\prime \prime} \mathrm{N} \\
15^{\circ} 53^{\prime} 57.7^{\prime \prime} \mathrm{E}\end{array}$ & $\begin{array}{l}\text { October/ } \\
2014\end{array}$ & $\begin{array}{c}\text { Pinus } \\
\text { halepensis }\end{array}$ & $\begin{array}{l}\text { Dendrolimus } \\
\text { pini }\end{array}$ & larvae & $\begin{array}{l}\text { Beauveria } \\
\text { bassiana }\end{array}$ & $\begin{array}{l}\text { Lithosol } \\
\text { pH } 8.4 \\
\text { very dry }\end{array}$ & $\begin{array}{l}\text { June/2019 } \\
\text { (summer) }\end{array}$ \\
\hline $\begin{array}{c}\text { Požega } \\
\text { (Milan Lug) }\end{array}$ & $\begin{array}{l}45^{\circ} 23^{\prime} 47.8^{\prime \prime} \mathrm{N} \\
17^{\circ} 58^{\prime} 37.4^{\prime \prime} \mathrm{E}\end{array}$ & $\begin{array}{l}\text { January/ } \\
2017\end{array}$ & $\begin{array}{c}\text { Quercus sp. } \\
\text { Fagus } \\
\text { sylvatica }\end{array}$ & $\begin{array}{l}\text { Calliteara } \\
\text { pudibunda }\end{array}$ & larvae & $\begin{array}{l}\text { Beauveria } \\
\text { bassiana }\end{array}$ & $\begin{array}{l}\text { Colluvial } \\
\text { pH } 7.7 \\
\text { semidry }\end{array}$ & $\begin{array}{l}\text { March/2020 } \\
\text { (spring) }\end{array}$ \\
\hline $\begin{array}{l}\text { Mrkopalj } \\
\text { (Sungerski } \\
\text { Lug) }\end{array}$ & $\begin{array}{l}45^{\circ} 19^{\prime} 57.9^{\prime \prime} \mathrm{N} \\
14^{\circ} 47^{\prime} 31.6^{\prime \prime} \mathrm{E}\end{array}$ & $\begin{array}{l}\text { February / } \\
2017\end{array}$ & Picea abies & $\begin{array}{c}\text { Ips } \\
\text { typographus }\end{array}$ & adults & $\begin{array}{l}\text { Beauveria } \\
\text { bassiana }\end{array}$ & $\begin{array}{l}\text { Dystric } \\
\text { cambisol } \\
\text { pH } 4.9 \\
\text { semidry }\end{array}$ & $\begin{array}{l}\text { July / } 2019 \\
\text { (summer) }\end{array}$ \\
\hline $\begin{array}{c}\text { Dugi otok } \\
\text { (Nature } \\
\text { Park } \\
\text { Telašćica) }\end{array}$ & $\begin{array}{l}43^{\circ} 53^{\prime} 19.4^{\prime \prime} \mathrm{N} \\
15^{\circ} 09^{\prime} 41.9^{\prime \prime} \mathrm{E}\end{array}$ & $\begin{array}{c}\text { September / } \\
2017\end{array}$ & $\begin{array}{c}\text { Pinus } \\
\text { halepensis }\end{array}$ & $\begin{array}{l}\text { Dendrolimus } \\
\text { pini }\end{array}$ & larvae & $\begin{array}{l}\text { Beauveria } \\
\text { bassiana }\end{array}$ & $\begin{array}{c}\text { Regosol } \\
\text { pH } 8.0 \\
\text { dry }\end{array}$ & $\begin{array}{c}\text { November/ } \\
2018 \\
\text { (autumn) }\end{array}$ \\
\hline $\begin{array}{l}\text { Spačva } \\
\text { (Manage- } \\
\text { ment Unit } \\
\text { Ceranski } \\
\text { lugovi) }\end{array}$ & $\begin{array}{l}45^{\circ} 10^{\prime} 41.3^{\prime \prime} \mathrm{N} \\
18^{\circ} 43^{\prime} 54.9^{\prime \prime} \mathrm{E}\end{array}$ & $\begin{array}{l}\text { May/ } \\
2018\end{array}$ & Quercus robur & $\begin{array}{c}\text { Corythucha } \\
\text { arcuata }\end{array}$ & adults & $\begin{array}{l}\text { Beauveria } \\
\text { pseu- } \\
\text { dobassiana }\end{array}$ & $\begin{array}{c}\text { Mollic } \\
\text { humogley } \\
\text { pH 7.8 } \\
\text { very wet }\end{array}$ & $\begin{array}{c}\text { February/ } \\
2019 \text { (winter) }\end{array}$ \\
\hline
\end{tabular}

From each sampling site, samples were taken at five randomly chosen points, at least $100 \mathrm{~m}$ away from each other. Five samples per point were taken from each site, so altogether 125 soil samples were collected. Before soil sampling, surface particles and leaf litter were removed from the soil surface. The samples were taken using a shovel (which was disinfected in 70\% EtOH between each sampling), from a depth of 10-15 cm. The samples were then placed in sterile plastic vessels $(10 \times 10 \mathrm{~cm})$ and brought to the Croatian Forest Research Institute for further laboratory analysis. They were kept at a temperature of $3-4{ }^{\circ} \mathrm{C}$ until isolation and were processed within $48 \mathrm{~h}$ of collection, according to Tkaczuk et al. [26]. The soil samples were mixed thoroughly, sieved with $3 \mathrm{~mm}$ mesh 
to separate debris (e.g., pebbles, twigs, and roots), and dried to a moisture content of approximately $25-30 \%$.

\subsection{Isolation of Fungi}

Fungi were isolated from the soil using a selective medium method adapted from Strasser et al. [20]. The medium was prepared with $1 \mathrm{~L}$ of distilled deionized water, $20 \mathrm{~g}$ of glucose (Difco ${ }^{\mathrm{TM}}$, Becton Dickinson and Company, Franklin Lakes, NJ, USA), $18 \mathrm{~g}$ of agar (Bacto ${ }^{\mathrm{TM}}$, Becton Dickinson and Company, Franklin Lakes, NJ, USA), $10 \mathrm{~g}$ of peptone (Difco ${ }^{\mathrm{TM}}$, Becton Dickinson and Company, Franklin Lakes, NJ, USA), and selective components (i.e., components that inhibit the growth of saprophytic fungi and bacteria, and permit the uninhibited growth of entomopathogenic fungi): $0.6 \mathrm{~g}$ of streptomycin sulfate (Sigma-Aldrich ${ }^{\circledR}$, St. Louis, MO, USA), $0.05 \mathrm{~g}$ of chlortetracycline (Sigma-Aldrich ${ }^{\circledR}$, St. Louis, MO, USA), $0.05 \mathrm{~g}$ of cycloheximide (Alfa Aesar ${ }^{\mathrm{TM}}$, Thermo Fisher Scientific, Haverhill, MA, USA) and $0.1 \mathrm{~g}$ of dodine (Pestanal ${ }^{\circledR}$, Sigma-Aldrich, St. Louis, MO, USA). Two grams of soil from each sample were weighed and then mixed with sterile distilled water with the added surfactant Tween $(0.05 \%)$, in a ratio of $1: 10$ or $1: 100$. Tubes (Corning ${ }^{\circledR}$, New York, NY, USA, $50 \mathrm{~mL}$ ) with the solutions were shaken vigorously for about 30-40 s, after which $100 \mu \mathrm{L}$ of the solutions were pipetted and evenly distributed with a sterile triangular spatula into Petri dishes with a selective nutrient medium. Three replicates for each solution were prepared and incubated at $23 \pm 1{ }^{\circ} \mathrm{C}$ for $10-14$ days. To assess the density of EPF in tested soils, colonies of individual fungal species were counted and recorded, and results were expressed as a number of colony-forming units (CFU) of fungi per $1 \mathrm{~g}$ of dry soil. Colonies were subcultured in a potato dextrose agar (PDA) medium to obtain pure cultures for further analysis. After dividing the fungal cultures into morphotype groups, a total of 42 representative isolates were selected for further morphological and molecular analysis. Fungal cultures were deposited in the Laboratory of Phytopathological Analysis at the Croatian Forest Research Institute (Jastrebarsko, Croatia).

\subsection{Identification of Fungal Species}

The initial identification of fungal species was made by macroscopic (colony morphology) and microscopic (microstructure morphology) characteristics, using standard identification keys $[27,28]$. Fungal genomic DNA was prepared from fresh plate cultures of all 42 fungal isolates with the NucleoSpin Plant II Kit (Macherey-Nagel, Düren, Germany), following the manufacturer's instructions.

The primers ITS 1-F (5'-CTTGGTCATTTAGAGGAAGTA-3') [29] and ITS4 (5'-TCCTCC GCTTATTGATATGC-3') [30] were used to amplify the fungal ITS (internal transcribed spacer) regions. PCR conditions were as follows: initial denaturation at $95^{\circ} \mathrm{C}$ for $5 \mathrm{~min}$; 34 cycles of $95^{\circ} \mathrm{C}$ for $15 \mathrm{~s} ; 52^{\circ} \mathrm{C}$ for $30 \mathrm{~s} ; 72{ }^{\circ} \mathrm{C}$ for $1.5 \mathrm{~min}$; and final elongation at $72{ }^{\circ} \mathrm{C}$ for $7 \mathrm{~min}$. All reactions were checked for amplification by gel electrophoresis, visualized with UV illumination, and the PCR products were sequenced by Macrogen Europe (Amsterdam, The Netherlands). The resulting sequences were delivered electronically, and sequence reads were analyzed and edited using Geneious Prime. The obtained sequences were submitted to a GenBank and compared with similar sequences through the Basic Local Alignment Search Tool (BLAST) of NCBI Gene Bank. Unfortunately, since we used only the ITS region for the identification of fungi in this study, there was not sufficient variation for differentiating among some of the species, so the study was performed only at a genus level for all the analyzed sequences.

\subsection{Statistical Analysis}

Statistical analysis of obtained results was conducted using software Windows Excel Ink. The differences among the mean numbers of colony-forming units (CFU) of entomopathogenic fungi per $1 \mathrm{~g}$ of soil were tested for different fungal genera obtained in five localities in Croatia by two-way analysis of variance (ANOVA), using Tukey's honest significant difference test. Values of $p<0.05$ were considered statistically significant. 


\section{Results}

A total of 42 representative fungal isolates obtained from soil samples at five locations in forests in Croatia were selected for further analysis: Dugitok (8), Skradin (11), Spačva (7), Mrkopalj (8), and Požega (8). After morphological and molecular analysis, it was confirmed that 26 of them belong to five genera of EPF: Beauveria spp., Metarhizium spp., Purpureocillium spp., Lecanicillium spp., and Paecilomyces spp.; two belong to genera Tolypocladium spp. and Trichosporon spp. (fungi with potential entomopathogenic abilities); and 14 belong to fungal genera that have not yet demonstrated pathogenicity on insects, but which may be pathogenic on other organisms (e.g., species of the genus Pochonia that are pathogenic on harmful soil nematodes and are developed and commercialized as biological pesticides) (Table 2). This also shows that the selective nutrient medium intended for the isolation of exclusively entomopathogenic fungi [20] is not selective for these species.

Table 2. Identified fungal species and the density of their colony-forming units $\left(\mathrm{CFU} \times 10^{3} \mathrm{~g}^{-1}\right)$ in soil.

\begin{tabular}{|c|c|c|c|c|c|}
\hline \multirow{2}{*}{$\begin{array}{l}\text { Identified } \\
\text { Species }\end{array}$} & \multicolumn{5}{|c|}{ Average Number of CFU in $1 \mathrm{~g}$ of Soil at Different Sampling Locations (CFU $\times 10^{3} \mathrm{~g}^{-1}$ ) } \\
\hline & $\begin{array}{c}\text { Location } 1 \\
\text { (Dugi Otok) }\end{array}$ & $\begin{array}{l}\text { Location } 2 \\
\text { (Skradin) }\end{array}$ & $\begin{array}{l}\text { Location } 3 \\
\text { (Spačva) }\end{array}$ & $\begin{array}{r}\text { Location } 4 \\
\text { (Mrkopalj) }\end{array}$ & $\begin{array}{c}\text { Location } 5 \\
\text { (Požega) }\end{array}$ \\
\hline \multicolumn{6}{|c|}{ Entomopathogenic fungi } \\
\hline Beauveria spp. & 2.6 & 5.3 & 4 & 6.2 & - \\
\hline Metarhizium spp. & 0.4 & - & - & 11 & 20 \\
\hline Purpureocillium spp. & 4.4 & 17 & - & 0.6 & - \\
\hline Lecanicillium spp. & 1 & 0.3 & - & - & 1 \\
\hline Paecilomyces spp. & - & - & - & - & 6.4 \\
\hline$\sum$ & 8.4 & 22.6 & 4 & 17.8 & 27.4 \\
\hline \multicolumn{6}{|c|}{ Fungi with potential entomopathogenic abilities } \\
\hline Tolypocladium spp. & - & - & - & 0.2 & - \\
\hline Trichosporon spp. & - & - & - & - & 1.6 \\
\hline \multicolumn{6}{|c|}{ Fungi of unproven entomopathogenic abilities } \\
\hline Pochonia spp. & 10 & 3.3 & 8.7 & 5.4 & - \\
\hline Absidia spp. & 0.08 & - & & - & 5 \\
\hline $\begin{array}{l}\text { Pseudogymnoascus } \\
\text { spp. }\end{array}$ & - & - & 0.6 & - & - \\
\hline$\sum$ & 10.1 & 3.3 & 9.3 & 5.6 & 6.6 \\
\hline Total $\sum$ & 18.5 & 25.9 & 13.3 & 23.4 & 34 \\
\hline
\end{tabular}

The density of colony-forming units (CFU) of EPF was obtained by calculating the average number of colonies in $1 \mathrm{~g}$ of soil, per replicate and at points in each location. The calculations showed that the range of total EPF colony density in the soil varies from $4 \times 10^{3}$ to $27.4 \times 10^{3} \mathrm{CFU} \mathrm{g}^{-1}$. The highest overall average number (density) of entomopathogenic fungal colonies was recorded at Location 5 (Požega), while the lowest was recorded at Location 3 (Spačva) (Table 2).

The highest average number (density) of colonies belonged to the genus Metarhizium, with $6.28 \times 10^{3} \mathrm{CFU}^{-1}$, but this was not significantly different from the density of Beauveria $\left(3.24 \times 10^{3} \mathrm{CFU} \mathrm{g}^{-1}\right)$ or Purpureocillium $\left(3.09 \times 10^{3} \mathrm{CFU} \mathrm{g}^{-1}\right)$, while Paecilomyces and Lecanicillium were clearly less abundant in Croatia (Tables 3 and 4, Figure 1). 
Table 3. Comparison of the number of colony-forming units $\left(\mathrm{CFU} \mathrm{g}^{-1}\right)$ in soil, by entomopathogenic fungi and localities using a two-way analysis of variance (ANOVA).

\begin{tabular}{ccccccc}
\hline Scheme & SS & Df & MS & $\boldsymbol{F}$ & p-Value & F Crit \\
\hline Entomopathogenic fungi & 510.3603 & 4 & 127.5901 & 5.027412 & 0.000984 & 2.462615 \\
Locality & 335.4643 & 4 & 83.86608 & 3.304562 & 0.013775 & 2.462615 \\
Entomopathogenic & 2015.057 & 16 & 125.9411 & 4.962436 & $2.15 \times 10^{-7}$ & 1.745647 \\
fungi*Locality & 2537.888 & 100 & 25.37888 & & \\
Error & 5398.77 & 124 & & & \\
Total & &
\end{tabular}

Table 4. Comparison of the mean number of fungal colony-forming units $\left(\mathrm{CFU} \mathrm{g}{ }^{-1}\right)$ in soil in the localities, using the Tukey's method to compare CFU estimates ( ${ }^{*}$ indicates significance at $p<0.05$ ).

\begin{tabular}{ccc}
\hline Comparison & Absolute Difference & Critical Value \\
\hline Beauveria vs. Lecanicillium & 2.72 & 3.6303 \\
Beauveria vs. Metarhizium & 3.12 & 3.6303 \\
Beauveria vs. Paecilomyces & 1.28 & 3.6303 \\
Beauveria vs. Purpureocillium & 3.096 & 3.6303 \\
Lecanicillium vs. Metarhizium & $5.84^{*}$ & 3.6303 \\
Lecanicillium vs. Paecilomyces & 0.76 & 3.6303 \\
Lecanicillium vs. Purpureocillium & 2.576 & 3.6303 \\
Metarhizium vs. Paecilomyces & $5.08^{*}$ & 3.6303 \\
Metarhizium vs. Purpureocillium & 3.264 & 3.6303 \\
Paecilomyces vs. Purpureocillium & 1.816 & 3.6303 \\
\hline
\end{tabular}

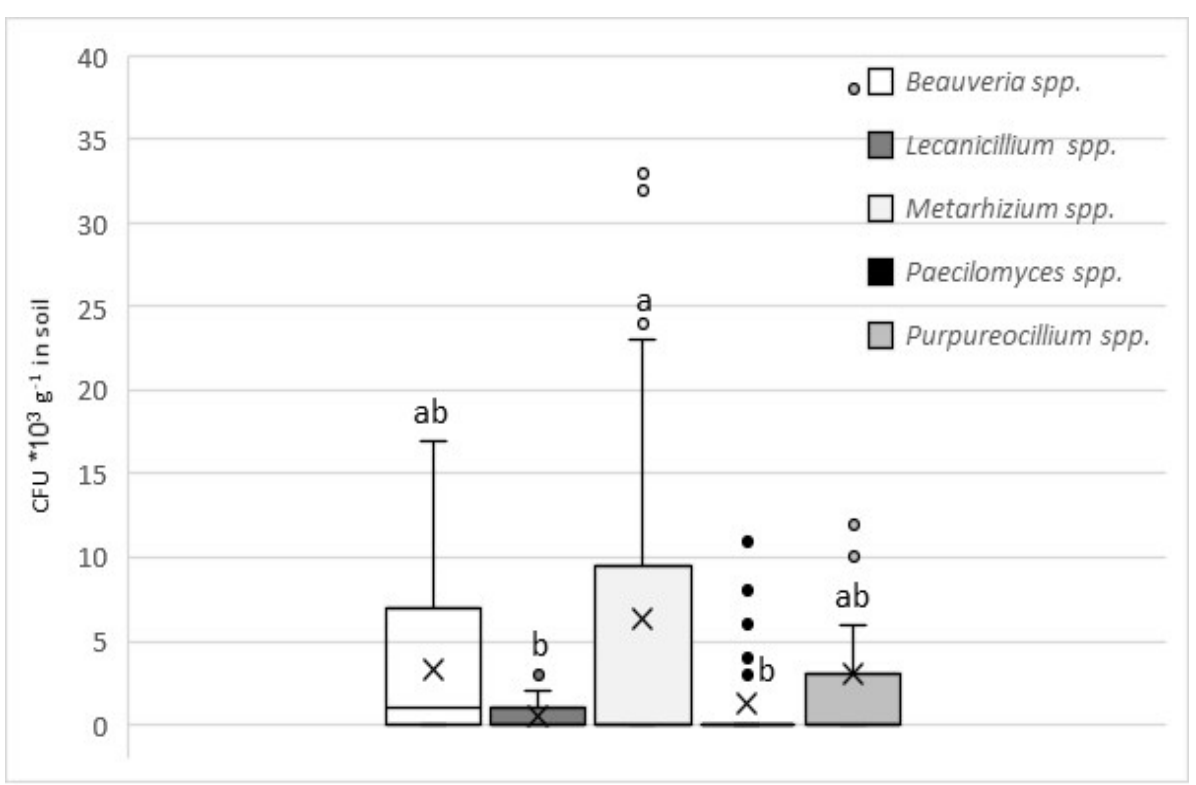

Figure 1. The amount of colony-forming units $\left(\mathrm{CFU} \mathrm{g} \mathrm{g}^{-1}\right)$ in soil, considering species of entomopathogenic fungi found. Letters above the bars indicate significant differences between treatments at $p<0.05$ when compared using Tukey's test (x-mean; box $25 \%$ and $75 \%$ quartile; whiskers-minimum and maximum).

The most common were EPF of the genus Beauveria, which were recorded at four of the five locations, and at 16 of the 25 sampling points. Their total share was $22 \%$. Only at Location 3 was their share 100\%; at other locations it was 31\% (Location 1), 24\% (Location 2), and 35\% (Location 4), respectively, while at Location 5 these fungi were not found at any sampling point. The largest total share of identified fungi belonged to the genus Metarhizium (38\%), followed by genera Purpureocillium (27\%) and Beauveria (22\%). At 
Locations 1, 4, and 5, a higher diversity of EPF was observed than at Locations 2 and 3 (Figure 2).

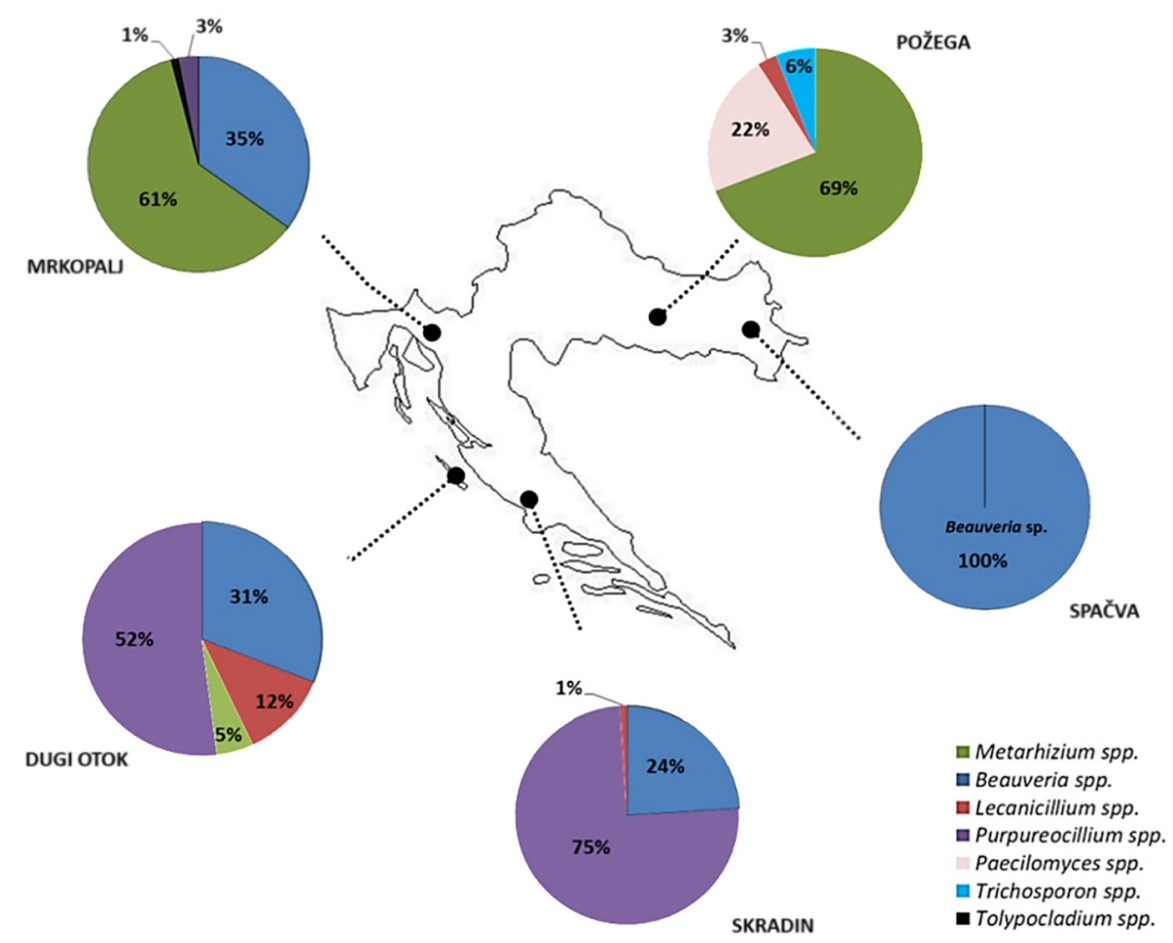

Figure 2. The share of identified species of fungi in the soil by location.

\section{Discussion}

In studies of the natural occurrence of EPF in the soil, specific methods are being used to recover fungal isolates. Although the insect bait method [21] is a commonly used and sensitive method for detection [31-33], it requires an investment of more time and effort than the method of isolation on a selective culture medium [20], and in some research where both methods were used the selective medium was more effective and provided a higher overall detection rate [34,35]. Here, we used a selective medium method not only to identify the diversity of entomopathogens and their distribution in soils throughout Croatia, but also to determine the number of colony-forming units (CFU) per gram of dry soil. Given that molecular analyses were conducted with primers ITS 1-F and ITS 4 (internal transcriptional spacer), which for many groups of fungi are not sufficient for exact delimitation of species within the genera (especially those that are closely related [36]), the isolates were identified at the genus level.

The results demonstrated that different species of EPF are present in the sampled soils in Croatia, and their diversity and density of occurrence varied depending on the study localities. Their adaptation to soil life represents the potential to infect harmful insects that spend parts of their life cycles right there, as demonstrated in a study by Matek and Pernek [8], where the entomopathogen Beauveria bassiana (Balsamo) Vuillemin (Hypocreales: Cordycipitaceae) caused mortality in over $98 \%$ of the population of the pine-tree lappet moth Dendrolimus pini (L.) (Lepidoptera: Lasiocampidae), during their overwintering in the soil. After complete defoliation of about 20 ha of Aleppo pine stands, the fungus broke down the population of that pest, which was followed by an almost complete recovery of the trees. This shows the great contribution that EPF can make in maintaining the natural balance of a single biocenosis. Results in this research show that these fungi are naturally present in the soil at locations where larvae became infected, and detailed inspection of needles that were initially suspected of representing a source of infection showed no evidence of fungal endophytic presence [24], which confirms that infections most likely occurred through the soil. Although B. bassiana can provide 
protection from different pests and diseases in some plants, as a naturally occurring $[37,38]$ or artificially inoculated endophyte [39-41], in some plants endophytic colonization of this fungus cannot be established [42,43], or the colonization remains in the root zone where it can persist for a longer period of time [44,45] and thus provide protection from insects that spend at least part of their development cycle in the soil.

In a fir bark beetle study close to the locality of Mrkopalj (Location 4 in our study), the mortality of the beetles Pityokteines spp. (Coleoptera: Scolytidae) caused by B. bassiana was $9 \%$ on average [25]. In this study, B. bassiana was the most reductive factor among entomopathogens, where infected beetles were found under bark covered by mycelium. Fir bark beetles overwinter under the bark of trees, but whether a part of the population stays in the soil (as is the case for other bark beetles [46]) is uncertain. Possibly, they come into contact with spores and transport them in the bark, where other beetles get infected. Combinations of pheromone traps with spores of B. bassiana in a catch-and-release context have shown the possibility of transporting spores under the bark [47].

The largest total share of identified fungi in this research belonged to the genus Metarhizium, followed by genera Purpureocillium and Beauveria. Those hypocrealean fungal genera are ubiquitous components of forest soils in temperate regions $[34,48,49]$. Although the highest average number (density) of colonies belonged to the genus Metarhizium, those fungi were found in three of the five localities, in comparison with genus Beauveria that was found to be naturally present in forest soils in most of the investigated localities (i.e., four of the five) and at the highest number of sampling points (16 of the 25). The dominance of $B$. bassiana in soils collected from various types of forests is also confirmed by studies conducted in Denmark [50], Finland [51], Poland [12,52,53], Japan [54], Italy [55], Spain [56,57], Austria [58], Mexico [59], Brazil [60], and Portugal [61]. In other research, Metarhizium was also the most abundant fungal genus detected [e.g., 31,35,58,62,63], with variable proportions of other species. Tkaczuk et al. [35,58] and Kleespies et al. [62] found that species from the genus Isaria was the second-most commonly detected fungus, with Beauveria in third place;Keller et al. [31] and Bidochka et al. [63] found that Beauveria was the second most prevalent genus, and Paecilomyces was the third. Popowska-Nowak et al. [64] found that Metarhizium anisopliae (Metschn.) Sorokin and Isaria fumosorosea (Wize) Brown and Smith were also the most frequent species of EPF in soils of forest plantations in Poland, especially in spring. Interestingly, Isaria, Paecilomyces, and Purpureocillium are taxonomically very closely related, and those genera went through a turbulent taxonomic history [65]. Samson [66] transferred all species in Isaria to Paecilomyces Bainer (1907), whereas Luangsa-ard et al. [67] moved Paecilomyces lilacinus (Thom) Samson to Purpureocillium in Ophiocordycipitaceae. In this research, the genus Purpureocillium was most abundant in localities in the Mediterranean part of Croatia, and second most abundant in the total share of identified species in the study. Niu et al. [68] demonstrated a prevalence of the Purpureocillium fungi in the soil of all sampled regions, with P. lilacinum as an absolutely dominant species. That study was conducted in the southern part of China, located in tropical and southern subtropical areas characterized by hot summers and mild winters, climatic conditions that can be compared to those of the Mediterranean Basin. It is believed that more Purpureocillium species will be discovered in the future [68]. Fungal species from those genera have been previously evaluated as entomopathogenic towards different insect pests, with great potential for use in biological pest control [10,19,45,59,69-72].

Fungi from the genus Lecanicillium W. Gams \& Zare occur on a diverse range of insect species, and have been isolated from forest soils around the world [12,49,64,73,74] and utilized for the control of different pests $[75,76]$. This genus was found at three studied locations, with a $12 \%$ share at Location 1, but in the total share of the identified entomopathogenic fungal species at all locations, it represented only $3 \%$.

Genus Trichosporon Behrend is widely distributed in nature and can be found in soils mostly in tropical and temperate areas $[77,78]$. Some species are commonly recognized as opportunistic pathogens, and several species were isolated from insects [79-81]. Species from the genus Tolypocladium W. Gams are known inhabitants of soils [82], with some com- 
monly found in cold soils [83-85]. Many species produce compounds with demonstrated insecticidal and antifungal activity [86]; some research indicates that their alternate hosts in the soil can be nematodes [87]. In this study, those two genera were found in small shares $(2 \%$ and $0.2 \%)$ of the identified species, compared to a total share at all locations, with Trichosporon found only at Location 5 and Tolypocladium found only at Location 4 . The entomopathogenic potential of these fungi should be further investigated. Due to their rare occurrence, these genera were not included in the statistical analyses.

Species composition, frequency, and the number of colonies depends on different factors such as geographical location, type of habitat, microclimatic conditions (temperature and humidity), and time of year (which determines the activity of insects in the soil environment and the transfer of spores and other forms of fungal propagation) $[11,12,51,63,64]$, as well as the use of chemical pesticides, especially fungicides that can change the occurrence, infectivity, and population dynamics of EPF in the soil [68,88-90]. In general, EPF are more abundant in soils that have less disturbance $[1,34,91]$. To some extent, this could explain why at Location 3 there was the least diversity of species recorded, in comparison with other locations; however, more research would be needed to clarify this result. In this type of study, a larger number of soil samples, a reduction in the distances between sample points, and a denser sampling grid (i.e., a higher number of points and locations) can change the final result of the number and diversity of EPF in an area $[33,68]$. This would probably be the case here, so a more detailed investigation is necessary. Nevertheless, these results are the first to provide an insight into the occurrence, distribution, and diversity of soil EPF in Croatia, and establish a basis for future similar research, including the inclusion of the influence of other features such as soil type, $\mathrm{pH}$ of the soil, tree species, potential host density, etc. Results of our study clearly show that future research of entomopathogens in forest soils should take into account the forest type, to involve variability in relation to the dominant pest species and host trees. the Conduction of pathogenicity assays that would prove the infectivity potential of EPF found is crucial. Such studies can be useful for selecting and utilizing entomopathogens that are suitable for biological pest control in certain target areas, and may designate candidates for suppression of major forest pest threats in Croatia, such as the Mediterranean bark beetle [92], the oak lace bug [24], and jewel beetles associated with bacteria [Pernek, in prep.] in an effective but ecologically acceptable way.

Author Contributions: Conceptualization, M.K. and C.T.; methodology, C.T. and M.K.; formal analysis, M.K.; investigation, M.K.; data curation, M.P.; writing—original draft preparation, M.K.; writing - review and editing, M.P. and C.T.; visualization, M.K.; supervision, M.P. All authors have read and agreed to the published version of the manuscript.

Funding: This work was financially supported by the Ministry of Agriculture (Diagnostic and Prognostic Service) of Croatia.

Data Availability Statement: The data presented in this study are available within the article.

Acknowledgments: We thank Josip Kovač, Nikola Lacković, Ivana Mihaljević, and Valter Floigl for help during the collection of samples. We would also like to thank the employees of Croatian Forests Ltd. for providing us with information on forest habitats at our sampling sites.

Conflicts of Interest: The authors declare no conflict of interest.

\section{References}

1. Klingen, I.; Eilenberg, J.; Meadow, R. Effects of farming system, field margins and bait insect on the occurrence of insect pathogenic fungi in soils. Agric. Ecosyst. Environ. 2002, 91, 191-198. [CrossRef]

2. Eilenberg, J.; Schmidt, N.M.; Meyling, N.; Wolsted, C. Preliminary survey for insect pathogenic fungi in Arctic Greenland. IOBC/WPRS Bull. 2007, 30, 12.

3. Bridge, P.D.; Worland, M.R. First report of an entomophthoralean fungus on an arthropod host in Antarctica. Polar. Biol. 2004, 27, 190-192. [CrossRef]

4. Bridge, P.D.; Clark, M.S.; Pearce, D.A. A new species of Paecilomyces isolated from the Antarctic springtail Cryptopygus antarcticus. Mycotaxon 2005, 92, 213-222. 
5. Aoki, J. Mixed infection of the gypsy moth, Lymantria dispar japonica Motschulsky (Lepidoptera: Lymantriidae), in a larch forest by Entomophaga aulicae (Reich.) Sorok. and Paecilomyces canadensis (Vuill.) Brown et Smith. Appl. Entomol. Zool. 1974, 9, 185-190. [CrossRef]

6. Fuxa, J.R.; Tanada, Y. Epizootiology of Insect Diseases; Wiley-Interscience: New York, NY, USA, 1987.

7. Hicks, B.J.; Watt, A.D. Fungal disease and parasitism in Panolis flammea during 1998: Evidence of change in the diversity and impact of the natural enemies of a forest pest. Forestry 2000, 73, 31-36. [CrossRef]

8. Matek, M.; Pernek, M. First Record of Dendrolimus pini Outbreak on Aleppo Pine in Croatia and Severe Case of Population Collapse Caused by Entomopathogen Beauveria bassiana. South-East Eur. For. 2018, 9, 91-96. [CrossRef]

9. Jackson, T.A.; Alves, S.B.; Pereira, R.M. Success in biological control of soil-dwelling insects by pathogens and nematodes. In Biological Control: Measures of Success; Gurr, G., Wratten, S., Eds.; Kluwer Academic Publisher: Dordrecht, The Netherlands, 2000; pp. 271-296. [CrossRef]

10. Zimmermann, G. The entomopathogenic fungi Isaria farinosa (formerly Paecilomyces farinosus) and the Isaria fumosorosea species complex (formerly Paecilomyces fumosoroseus): Biology, ecology and use in biological control. Biocontrol Sci. Technol. 2008, 18, 865-901. [CrossRef]

11. Quesada-Moraga, E.; Navas-Cortés, J.A.; Maranhao, E.A.; Ortiz-Urquiza, A.; Santiago-Álvarez, C. Factors affecting the occurrence and distribution of entomopathogenic fungi in natural and cultivated soils. Mycol. Res. 2007, 111, 947-966. [CrossRef]

12. Majchrowska-Safaryan, A.; Tkaczuk, C. Abundance of Entomopathogenic Fungi in Leaf Litter and Soil Layers in Forested Habitats in Poland. Insects 2021, 12, 134. [CrossRef]

13. Steenberg, T.; Langer, V.; Esbjerg, P. Entomopathogenic fungi in predatory beetles (Col.: Carabidae and Staphylinidae) from agricultural fields. Entomophaga 1995, 40, 77-85. [CrossRef]

14. Hajek, A.E. Ecology of terrestrial fungal entomopathogens. Adv. Microb. Ecol. 1997, 15, 193-249. [CrossRef]

15. Ekesi, S.; Dimbi, S.; Maniania, N.K. The role of entomopathogenic fungi in the integrated management of fruit flies (Diptera: Tephritidae) with emphasis on species occurring in Africa. In Use of Entomopathogenic Fungi in Biological Pest Management; Maniana, K., Ekesi, S., Eds.; Research SignPosts: Trivandrum, India, 2007; pp. 239-274.

16. Gaugler, R. Ecological considerations in the biological control of soil-inhabiting insects with entomopathogenic nematodes. Agric. Ecosyst. Environ. 1988, 24, 351-360. [CrossRef]

17. Solter, L.F.; Hajek, A.E.; Lacey, L.A. Exploration for entomopathogens. In Microbial Control of Insect and Mite Pests; Lacey, L.A., Ed.; Academic Press: London, UK, 2017; pp. 13-23. [CrossRef]

18. Keller, S.; Zimmermann, G. Mycopathogens of soil insects. In Insect-Fungus Interactions; Wilding, N., Collins, N.M., Hammond, P.M., Webber, J.F., Eds.; Academic Press: London, UK, 1989; pp. 239-270. [CrossRef]

19. Inglis, G.D.; Goettel, M.S.; Butt, T.M.; Strasser, H. Use of hyphomycetous fungi for managing insect pests. In Fungi as Biocontrol Agents; Butt, T.M., Jackson, C., Magan, N., Eds.; CABI Publishing: Wallingford, UK, 2001; pp. $23-69$.

20. Strasser, H.; Forer, A.; Schinner, F. Development of media for the selective isolation and maintenance of virulence of Beauveria brongniartii. In Proceedings of the Third International Workshop on Microbial Control of Soil Dwelling Pests; Jackson, T.A., Glare, T.R., Eds.; AgResearch: Lincoln, New Zealand, 1996; pp. 125-130.

21. Zimmermann, G. The 'Galleria bait method' for detection of entomopathogenic fungi in soil. J. Appl. Entomol. 1986, 102, 213-215. [CrossRef]

22. Goettel, M.; Inglis, D. Fungi: Hyphomycetes. In Manual of Techniques in Insect Pathology; Lacey, L.A., Ed.; Academic Press: Amsterdam, The Netherlands, 1997; pp. 213-249. [CrossRef]

23. Kovač, M.; Gorczak, M.; Wrzosek, M.; Tkaczuk, C.; Pernek, M. Identification of Entomopathogenic Fungi as Naturally Occurring Enemies of the Invasive Oak Lace Bug, Corythucha arcuata (Say) (Hemiptera: Tingidae). Insects 2020, 11, 679. [CrossRef]

24. Kovač, M. Entomopatogene Gljiva Roda Beauveria u Hrvatskoj i Mogućnosti Njihove Uporabe u Biološkoj Kontroli Šumskih Štetnika. Ph.D. Thesis, Faculty of Forestry and Wood Techonolgy, University of Zagreb, Zagreb, Croatia, 29 January 2021. (In Croatian).

25. Pernek, M.; Matošević, D.; Hrašovec, B.; Kučinić, M.; Wegensteiner, R. Ocurrence of pathogens in outbreak populations of Pityokteines spp. (Coleoptera, Curculionidae, Scolytinae) in silver fir forests. J. Pest. Sci. 2009, 82, 343-349. [CrossRef]

26. Tkaczuk, C.; Tipping, C.; Majchrowska-Safaryan, A.; Krol, A.; Wyrzykowska, M.; Wegensteiner, R. The occurrence of entomopathogenic fungi in soils from apple orchards protected in different farming systems. Fresen. Environ. Bull. 2019, 28, 7906-7914.

27. Humber, R.A. Identification of Entomopathogenic Fungi. In Manual of Techniques in Invertebrate Pathology; Lacey, L.A., Ed.; Academic Press: London, UK, 2012; pp. 151-187. [CrossRef]

28. Inglis, G.D.; Enkerli, J.; Goettel, M.S. Laboratory Techniques Used for Entomopathogenic Fungi: Hypocreales. In Manual of Techniques in Invertebrate Pathology; Lacey, L.A., Ed.; Academic Press: London, UK, 2012; pp. 189-253. [CrossRef]

29. Gardes, M.; Bruns, T.D. ITS primers with enhanced specificity for basidiomycetes-application to the identification of mycorrhizae and rusts. Mol. Ecol. 1993, 2, 113-118. [CrossRef]

30. White, T.J.; Bruns, T.; Lee, S.; Taylor, J. Amplification and direct sequencing of fungal ribosomal RNA genes for phylogenetics. In PCR Protocols: A Guide to Methods and Applications; Innis, M.A., Gelfand, D.H., Sninsky, J.J., White, T.J., Eds.; Academic Press: San Diego, CA, USA, 1990; pp. 315-322. [CrossRef] 
31. Keller, S.; Kessler, P.; Schweizer, C. Distribution of insect pathogenic soil fungi in Switzerland with special reference to Beauveria brongniartii and Metarhizium anisopliae. BioControl 2003, 48, 307-319. [CrossRef]

32. Bruck, D.J. Natural occurrence of entomopathogens in Pacific Northwest nursery soils and their virulence to the black vine weevil, Otiorhynchus sulcatus (F.) (Coleoptera: Curculionidae). Environ. Entomol. 2004, 33, 1335-1343. [CrossRef]

33. Meyling, N.V.; Eilenberg, J. Occurrence and distribution of soil borne entomopathogenic fungi within a single organic agroecosystem. Agric. Ecosyst. Environ. 2006, 113, 336-341. [CrossRef]

34. Medo, J.; Cagan, L. Factors affecting the occurrence of entomopathogenic fungi in soils of Slovakia as revealed using two methods. Biol. Control 2011, 59, 200-208. [CrossRef]

35. Tkaczuk, C.; Król, A.; Majchrowska-Safaryan, A.; Nicewicz, Ł. The occurrence of entomopathogenic fungi in soils from fields cultivated in a conventional and organic system. J. Ecol. Eng. 2014, 15, 137-144. [CrossRef]

36. Atkins, S.D.; Clark, I.M. Fungal molecular diagnostics: A mini review. J. Appl. Genet. 2004, 45, 3-15. [PubMed]

37. Reay, S.D.; Brownbridge, M.; Gicquel, B.; Cummings, N.J.; Nelson, T.L. Isolation and characterization of endophytic Beauveria spp. (Ascomycota: Hypocreales) from Pinus radiata in New Zealand forests. Biol. Control 2010, 54, 52-60. [CrossRef]

38. Donga, T.K.; Meadow, R.; Meyling, N.V.; Klingen, I. Natural Occurrence of Entomopathogenic Fungi as Endophytes of Sugarcane (Saccharum officinarum) and in Soil of Sugarcane Fields. Insects 2021, 12, 160. [CrossRef]

39. Rondot, Y.; Reineke, A. Endophytic Beauveria bassiana in grapevine Vitis vinifera (L.) reduces infestation with piercing-sucking insects. Biol. Control 2018, 116, 82-89. [CrossRef]

40. Barra-Bucarei, L.; France Iglesias, A.; Gerding González, M.; Silva Aguayo, G.; Carrasco-Fernández, J.; Castro, J.F.; Ortiz Campos, J. Antifungal activity of Beauveria bassiana endophyte against Botrytis cinerea in two solanaceae crops. Microorganisms 2020, 8, 65. [CrossRef]

41. Russo, M.L.; Jaber, L.R.; Scorsetti, A.C.; Vianna, F.; Cabello, M.N.; Pelizza, S.A. Effect of entomopathogenic fungi introduced as corn endophytes on the development, reproduction, and food preference of the invasive fall armyworm Spodoptera frugiperda. J. Pest. Sci. 2021, 94, 859-870. [CrossRef]

42. Ullrich, C.I.; Koch, E.; Matecki, C.; Schäfer, J.; Burkl, T.; Rabenstein, F.; Kleespies, R.G. Detection and growth of endophytic entomopathogenic fungi in dicot crop plants. J. Kult. 2017, 69, 291-302.

43. Koch, E.; Zink, P.; Ullrich, C.I.; Kleespies, R.G. Light microscopic studies on the development of Beauveria bassiana and other putative endophytes in leaf tissues. J. Kult. 2018, 70, 95-107.

44. Matek, M.; Ullrich, C.I.; Rabenstein, F.; Koch, E.; Kleespies, R.G. In situ immunofluorescence localization: A method for rapid detection of Beauveria spp. in the rhizosphere of Quercus robur saplings. J. Kult. 2019, 71, 211-218.

45. Coombes, C.A.; Hill, M.P.; Moore, S.D.; Dames, J.F. Entomopathogenic fungi as control agents of Thaumatotibia leucotreta in citrus orchards: Field efficacy and persistence. BioControl 2016, 61, 729-739. [CrossRef]

46. Kasumović, L.; Lindelow, A.; Hrašovec, B. Overwintering strategy of Ips typographus L. (Coleoptera, Curculionidae, Scolytinae) in Croatian spruce forests on lowest elevation. Sumar. List 2019, 1-2, 19-24. [CrossRef]

47. Kreutz, J.; Zimmermenn, G.; Mahron, H.; Vaupel, O.; Mosbacher, G. Preliminary investigations on the use of Beauveria bassiana (Bals.) Vuill. and other control methods against the bark beetle Ips typographus L. (Col., Scolytidae) in the Weld. IOBC/WPRS Bull. 2000, 23, 167-173.

48. Chandler, D.; Hay, D.; Reid, A.P. Sampling and occurrence of enthomopathogenic fungi and nematodes in UK soils. Appl. Soil. Ecol. 1997, 5, 133-140. [CrossRef]

49. Sun, B.D.; Liu, X.Z. Occurrence and diversity of insect-associated fungi in natural soils in China. Appl. Soil. Ecol. 2008, 39, 100-108. [CrossRef]

50. Steenberg, T. Natural Occurrence of Beauveria bassiana (Bals.) Vuill. with Focus on Infectivity to Sitona Species and Other Insects in Lucerne. Ph.D. Thesis, Royal Veterinary and Agricultural University, Copenhagen, Denmark, 1995.

51. Vänninen, I. Distribution and occurrence of four entomopatogenic fungi in Finland: Effect of geographical location, habitat type and soil type. Mycol. Res. 1996, 100, 93-101. [CrossRef]

52. Bajan, C.; Kmitowa, K.; Mierzejewska, E.; Popowska-Nowak, E.; Miętkiewski, R.; Górski, R.; Miętkiewska, Z.; Głowacka, B. The occurrence of entomopathogenic fungi in the bedding and soil of pine woods in the gradient of the forest environment pollution. Prace IBL Ser. B 1995, 24, 87-97. (In Polish)

53. Miętkiewski, R.; Dzięgielewska, M.; Janowicz, K. Entomopathogenic fungi isolated in the vicinity of Szczecin. Acta Mycol. 1998, $33,12-134$.

54. Shimazu, M.; Sato, H.; Maehara, N. Density of the entomopathogenic fungus, Beauveria bassiana Vuillemin (Deuteromycotina: Hyphomycetes) in forest air and soil. Appl. Entomol. Zool. 2002, 37, 19-26. [CrossRef]

55. Tarasco, E.; Bievre, C.; Papierok, B.; Poliseno, M.; Triggiani, O. Occurrence of entomopathogenic fungi in soils in Southern Italy. Entomologica 1997, 31, 157-166.

56. Asensio, L.; Carbonell, T.; Lopez-Jimenez, J.A.; Lopez-Llorca, L.V. Entomopathogenic fungi in soils from Alicante province. Span. J. Agric. Res. 2003, 1, 37-45. [CrossRef]

57. Maranhão, E.A.A.; Santiago-Alvarez, C. Occurrence of entomopathogenic fungi in soils from different parts of Spain. IOBC/WPRS Bull. 2003, 26, 59-62.

58. Tkaczuk, C.; Krzyczkowski, T.; Wegensteiner, R. The occurrence of entomopathogenic fungi in soils from mid-field woodlots and adjacent small scale arable fields. Acta Mycol. 2012, 47, 191-202. [CrossRef] 
59. Sánchez-Peña, S.R.; San-Juan Lara, J.; Medina, R.F. Occurrence of entomopathogenic fungi from agricultural and natural ecosystems in Saltillo, México, and their virulence towards thrips and whiteflies. J. Insect Sci. 2011, 11, 1. [CrossRef] [PubMed]

60. Mora, M.A.E.; Rouws, J.R.C.; Fraga, M.E. Occurrence of entomopathogenic fungi in Atlantic forest soils. Microbiol. Discov. 2016, 4, 1-7. [CrossRef]

61. Bueno-Pallero, F.A.; Blanco-Pérez, R.; Vicente-Díez, I.; Rodríguez Martín, J.A.; Dionísio, L.; Campos-Herrera, R. Patterns of occurrence and activity of entomopathogenic fungi in the Algarve (Portugal) using different isolation methods. Insects 2020, 11, 352. [CrossRef] [PubMed]

62. Kleespies, R.; Bathon, H.; Zimmermann, G. Untersuchen zum naturlichen Vorkommen von entomopathogenen Pilzen und Nematoden in verschiedenen Boden in der Umgebung von Darmstad. Gesunde Pflanzen 1989, 41, 350-355.

63. Bidochka, M.J.; Kasperski, J.E.; Wild, G.A.M. Occurrence of the entomopathogenic fungi Metarhizium anisopliae and Beauveria bassiana in soils from temperate and near- northern habitats. Can. J. Bot. 1998, 76, 1198-1204. [CrossRef]

64. Popowska-Nowak, E.; Skrzecz, I.; Tumialis, D.; Pezowicz, E.; Samborska, I.; Góral, K. Entomopathogenic fungi in the soils of forest plantations: Towards the control of large pine weevil, Hylobius abietis. Balt. For. 2016, 22, 8-15.

65. Mongkolsamrit, S.; Noisripoom, W.; Thanakitpipattana, D.; Wutikhun, T.; Spatafora, J.W.; Luangsa-Ard, J. Disentangling cryptic species with isaria-like morphs in Cordycipitaceae. Mycologia 2018, 110, 230-257. [CrossRef]

66. Samson, R.A. Paecilomyces and some allied hyphomycetes. Stud. Mycol. 1974, 6, 1-119. [CrossRef]

67. Luangsa-Ard, J.; Houbraken, J.; van Doorn, T.; Hong, S.B.; Borman, A.M.; Hywel-Jones, N.L.; Samson, R.A. Purpureocillium, a new genus for the medically important Paecilomyces lilacinus. FEMS Microbiol. Lett. 2011, 321, 141-149. [CrossRef]

68. Niu, X.; Xie, W.; Zhang, J.; Hu, Q. Biodiversity of entomopathogenic fungi in the soils of South China. Microorganisms 2019, 7, 311. [CrossRef]

69. Castillo Lopez, D.; Zhu-Salzman, K.; Ek-Ramos, M.J.; Sword, G.A. The entomopathogenic fungal endophytes Purpureocillium lilacinum (formerly Paecilomyces lilacinus) and Beauveria bassiana negatively affect cotton aphid reproduction under both greenhouse and field conditions. PLOS ONE 2014, 9, e103891. [CrossRef] [PubMed]

70. Toledo-Hernández, R.A.; Toledo, J.; Valle-Mora, J.; Holguín-Meléndez, F.; Liedo, P.; Huerta-Palacios, G. Pathogenicity and virulence of Purpureocillium lilacinum (Hypocreales: Ophiocordycipitaceae) on Mexican fruit fly adults. Fla. Entomol. 2019, 102, 309-314. [CrossRef]

71. Dunlap, C.A.; Jackson, M.A.; Wright, M.S. A foam formulation of Paecilomyces fumosoroseus, an entomopathogenic biocontrol agent. Biocontrol Sci. Technol. 2007, 17, 513-523. [CrossRef]

72. El-Sharabasy, H.M. Laboratory evaluation of the effect of the entomopathogenic fungi, Hirsutella thompsonii and Paecilomyces fumosoroseus, against the citrus brown mite, Eutetranychus orientalis (Acari: Tetranychidae). Plant Prot. Sci. 2015, 51, 39-45. [CrossRef]

73. González-Baca, G.; Vargas-Madriz, H.; Acuña-Soto, J.A.; González-Gaona, O.J.; Lázaro-Dzul, M.O.; Azuara-Domínguez, A. Distribution of entomopathogenic fungi in cultivated and noncultivated soils in Southern Tamaulipas, Mexico. Southwest. Entomol. 2019, 44, 139-142. [CrossRef]

74. Vivekanandhan, P.; Bedini, S.; Shivakumar, M.S. Isolation and identification of entomopathogenic fungus from Eastern Ghats of South Indian forest soil and their efficacy as biopesticide for mosquito control. Parasitol. Int. 2020, 76, 102099. [CrossRef]

75. Goettel, M.S.; Koike, M.; Kim, J.J.; Aiuchi, D.; Shinya, R.; Brodeur, J. Potential of Lecanicillium spp. for management of insects, nematodes and plant diseases. J. Invertebr. Pathol. 2008, 98, 256-261. [CrossRef]

76. Zhou, Y.; Zou, X.; Zhi, J.; Xie, J.; Jiang, T. Fast recognition of Lecanicillium spp., and its virulence against Frankliniella occidentalis. Front. Microbiol. 2020, 11, 561381. [CrossRef]

77. Colombo, A.L.; Padovan, A.C.B.; Chaves, G.M. Current knowledge of Trichosporon spp. and Trichosporonosis. Clin. Microbiol. Rev. 2011, 24, 682-700. [CrossRef] [PubMed]

78. Jamali, S.; Gharaei, M. The first isolation of Trichosporon coremiiforme from soil in Iran. Curr. Med. Mycol. 2015, 1, 3. [CrossRef] [PubMed]

79. Middelhoven, W.J.; Scorzetti, G.; Fell, J.W. Systematics of the anamorphic basidiomycetous yeast genus Trichosporon Behrend with the description of five novel species: Trichosporon vadense, T. smithiae, T. dehoogii, T. scarabaeorum and T. gamsii. Int. J. Syst. Evol. Microbiol. 2004, 54, 975-986. [CrossRef] [PubMed]

80. Molnar, O.; Schatzmayr, G.; Fuchs, E.; Prillinger, H. Trichosporon mycotoxinivorans sp. nov., a new yeast species useful in biological detoxification of various mycotoxins. Syst. Appl. Microbiol. 2004, 27, 661-671. [CrossRef]

81. Fuentefria, A.M.; Suh, S.O.; Landell, M.F.; Faganello, J.; Schrank, A.; Vainstein, M.H.; Blackwell, M.; Valente, P. Trichosporon insectorum sp.nov., a new anamorphic basidiomycetous killer yeast. Mycol. Res. 2008, 112, 93-99. [CrossRef]

82. Bissett, J. Notes on Tolypocladium and related genera. Can. J. Bot. 1983, 61, 1311-1329. [CrossRef]

83. Latter, P.M.; Heal, O.W. A preliminary study of the growth of fungi and bacteria from temperate and Antarctic soils in relation to temperature. Soil Biol. Biochem. 1971, 3, 365-379. [CrossRef]

84. Bissett, J.; Parkinson, D. The distribution of fungi in some alpine soils. Can. J. Bot. 1979, 57, 1609-1629. [CrossRef]

85. Khusnullina, A.I.; Bilanenko, E.N.; Kurakov, A.V. Microscopic fungi of White Sea sediments. Contemp. Probl. Ecol. 2018, 11, 503-513. [CrossRef]

86. Krasnoff, S.B.; Gupta, S. Identification and directed biosynthesis of efrapeptins in the fungus Tolypocladium geodes Gams (Deuteromycotina: Hyphomycetes). J. Chem. Ecol. 1991, 17, 1953-1962. [CrossRef] 
87. Samson, R.A.; Soares, G.G., Jr. Entomopathogenic species of the hyphomycete genus Tolypocladium. J. Invertebr. Pathol. 1984, 43, 133-139. [CrossRef]

88. Miętkiewski, R.T.; Pell, J.K.; Clark, S.J. Influence of pesticides use on the natural occurence of entomopathogenic fungi in arable soils in the UK. Field and laboratory comparisons. Biocontrol Sci. Technol. 1997, 7, 565-575. [CrossRef]

89. Klingen, I.; Haukeland, S. The soil as a reservoir for natural enemies of pest insects and mites with emphasis on fungi and nematodes. In An Ecological and Societal Approach to Biological Control; Eilenberg, J., Hokkanen, H.M.T., Eds.; Springer: Dordrecht, The Netherlands, 2006; pp. 145-211. [CrossRef]

90. Tkaczuk, C. Occurrence and Infective Potential of Entomopathogenic Fungi in Soils of Agrocenoses and Seminatural Habitats in the Agricultural Landscape; Scientific Dissertation no. 94; Wydawnictwo Akademii Podlaskiej: Siedlce, Poland, 2008. (In Polish)

91. Clifton, E.H.; Jaronski, S.T.; Hodgson, E.W.; Gassmann, A.J. Abundance of soil-borne entomopathogenic fungi in organic and conventional fields in the Midwestern USA with an emphasis on the effect of herbicides and fungicides on fungal persistence. PLoS ONE 2015, 10, e0133613. [CrossRef]

92. Pernek, M.; Lacković, N.; Lukić, I.; Zorić, N.; Matošević, D. Outbreak of Orthotomicus erosus (Coleoptera, Curculionidae) on Aleppo Pine in the Mediterranean Region in Croatia. South-East Eur. For. 2019, 10, 19-27. [CrossRef] 